\title{
シンポジウし I
}

\section{3 . 免疫学的異常}

\author{
松岡宏 \\ (名古屋大学小児科)
}

例えば，ウイルスが分泌型 $\operatorname{Ig} A$ バリアーを突 破し, 気道粘膜から血中へ侵入した場合, マク ロファージなど抗原提示細胞はこれを貪食, プ ロセッシングして自己 MHCとともに T, B 細 胞へ提示する。 $\mathrm{B}$ 細胞は細胞表面免疫グロブリ ンでこのウイルス抗原を受け止めて, 活性化さ れる。一方 T細胞は抗原受容体で MHC+抗原 をキャッチし, 活性化され, サイトカインを通 じて間接的に，かつ，CD40L/CD40などを介し て直接 B細胞に働いて, B 細胞をして抗ウイル 又抗体産生細胞へ, 増殖・分化させる。またT 細胞自身も増殖し, 細胞傷害性 $\mathrm{T}$ 細胞 (CTL) などへ分化する。その結果, フリーのウイルス 粒子は産生された抗体により中和される。一方, ヘルペス属など感染細胞内に潜んだウイルス は, 宿主細胞ごと, NK 細胞, K細胞あるいは CTLにより破壊される。細菌感染の場合も同様 に抗体が産生され, 抗体十補体による溶菌ある いは，抗体十補体がオプソニンとなって好中球 により頜食・殺菌される。以上の免疫系のいず れかが先天的に, 遺伝子異常などにより破綻し, 易感染性を呈するようになった疾患群を原発性 免疫不全症候群と総称する。現在までに約 30 種, 964例が厚生省特定疾患調査研究班に登録され ているが, 患者の $70 \%$ 以上が呼吸器感染を症状 として持ち, さらに呼吸器感染は死因の $50 \sim 70$ \%を占める。以下, 主な免疫不全症について自 験例を中心に紹介する。

1. 重症複合免疫不全症 (SCID) : B 細胞を 有する SCIDと T・B 細胞ともに著減した SCID に分けられる。前者は伴性型, 後者は常染 色体劣性遺伝を示すとされ, 伴性型については IL-2レセプター $\gamma$ 鎖遺伝子の異常と解明され ている。いずれも重篤な細胞性・液性免疫異常
（T細胞数・機能欠如，無 $\gamma$ グロブリン血症）に より, 細菌・真菌・ウイルス (特に CMV, HSV など）感染を反復し，カリニイ肺炎も致死的と なる。骨髄移植など根治療法が奏効しなければ 感染により死亡する。

2. 伴性無ガンマグロブリン血症 (XLA)・分 類不能型低ガンマグロブリン血症 (CVID) : CVID の一部でへルパーあるいはサプレッサー $\mathrm{T}$ 細胞機能異常を示す例があるものの，両疾患 ともに細胞性免疫は, ほぼ正常に保たれている。 前者は Btk 遺伝子異常, 後者は不明の病因によ る， B 細胞分化障害から無（低）ガンマグロブ

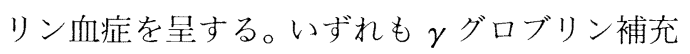
療法で治療される。

WHO 治療指針では従来, 致死的感染予防の 観点から血清 $\mathrm{IgG}$ 值を最低 $200 \mathrm{mg} / \mathrm{dl}$ 以上維持 するよう勧告してきた。1985年 Lederman ら は, 96例の XLA 成人例を調査し, $76 \%$ に反復・ 慢性呼吸器感染の合併を見, ほとんどの患者で 閉塞性〜混合性呼吸機能異常を認めて報告し た。また1987年 Gelfand らは, 半年間最低 IgG 值を500〜800 mg/dl に維持した結果 XLA 患 者呼吸機能の改善を見たと報告した。以上をふ まえてWHO委員会は最低 $\operatorname{IgG}$ 值200〜400 $\mathrm{mg} / \mathrm{dl}$ を, 補充療法目標値と変更した (Immunodeficiency Reviews Vol. 1, 1989)。

1987年我々も自験例（成人例）で呼吸機能を 検査し，2/4例で軽度拘束性障害を，また $3 / 4$ 例 で末梢気道の閉塞性障害を示唆する呼気曲線 $\dot{\mathrm{V}}_{50}, \dot{\mathrm{V}}_{25}$ /HT 低下を認めた (図 1 )。さらに, 1 年間血清 $\mathrm{IgG}$ 最低值を $500 \mathrm{mg} / \mathrm{dl}$ に維持する と, 患者の $\dot{\mathrm{V}}_{25} / \mathrm{HT}$ 值が改善することを併せて 報告し, 治療に関する全国アンケート結果も参 考として, $ン$ グロブリン補充療法は, 呼吸機能を 


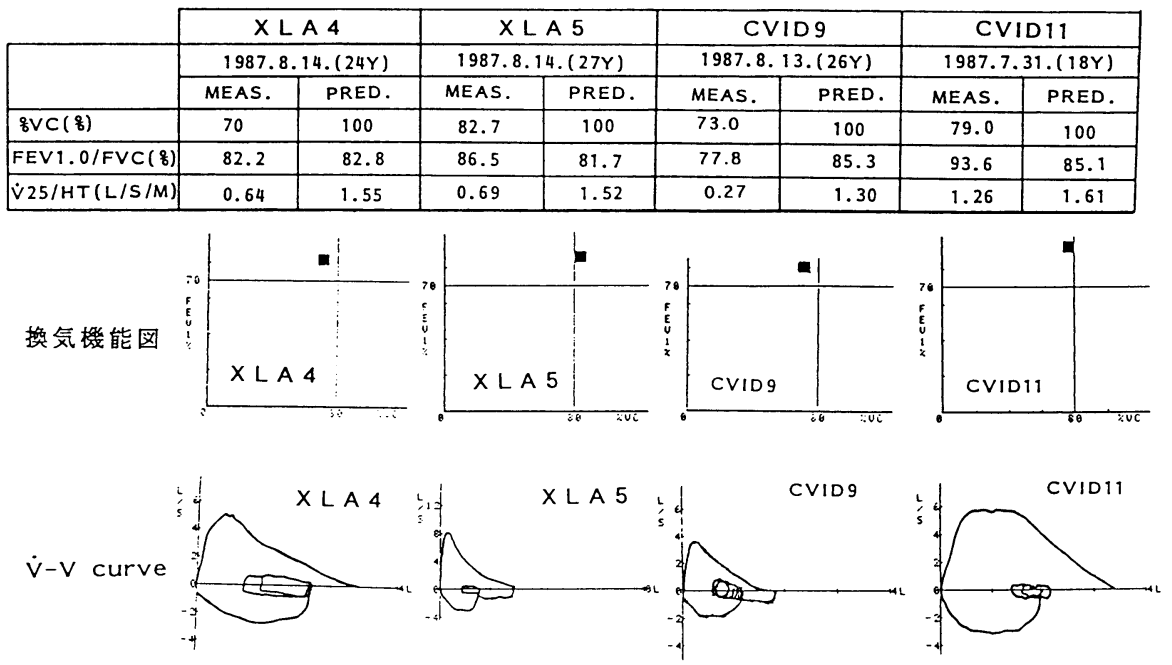

図 1 Pulmonary function test

指標としながら血清 $\mathrm{IgG} 400$ ～ $500 \mathrm{mg} / \mathrm{dl}$ を維 持することが望ましい旨,研究班に提言した(昭 和62年度免疫不全症候群調査研究班報告書：班 長；松本脩三)。

3. IgM 増加を伴う免疫不全 (HIM) : IgM から IgG, IgA へのクラススイッチ異常を示す 疾患である。伴性型については遺伝子がクロー ニングされて, T細胞表面の CD40L 分子異常 と判明した。その結果，クラススイッチは，サ イトカインによる段階と, T細胞 (CD40L)/B 細胞 (CD40) 直接作用の 2 段階を要すると推定 されるに至った。本症は，乳児期カリニイ肺炎 を合併すること，好中球減少症を伴うことも知 られている。 グロブリン療法で IgG $500 \mathrm{mg} /$ dl を維持したが，中耳炎，肺炎を反復し，感染 反復毎に IgM が増加, $\operatorname{IgM} 4,710 \mathrm{mg} / \mathrm{dl}$ まで 著増し，インフルエンザ菌から緑膿菌による肺 炎〜膿胸で死亡した例を供覧した。

4. Ataxia-telangiectasia：小脳性運動失 調・毛細血管拡張 - 免疫不全症と多臟器に及ぶ 異常で知られ, いずれも進行性である。常染色 体性劣性遺伝を示す。放射線感受性が強く, 染 色体脆弱性，リンパ・網内系悪性腫場好発もあ り，DNA 修復機構異常が背景として推定され ている。自験 3 家系 6 例の $10 \sim 20$ 年の臨床経過 をみると, 先ず小脳性運動失調が，次いで毛細 血管拡張が気付かれ，やがて幼児〜思春期頃か
ら呼吸器感染を反復するようになり 20 歳頃まで に悪性リンパ腫あるいは感染症で死亡する。そ れらの背景として $\mathrm{T} \rightarrow \mathrm{B}$ 細胞免疫系の進行性障 害が認められる。

5 . 慢性肉芽腫症 (CGD) : 伴性型と常染色 体性劣性 $(\mathrm{AR})$ 遺伝型がある。NADPH 酸化酵 素系異常により $\mathrm{O}_{2}^{-}$-産生障害を来し, 黄色ブ 菌, セラチアなどカタラーゼ産生菌による膿場, 肺炎を繰り返す。チトクローム b 558重鎖（伴 性), 軽鎖 (AR), NCF47 (AR), NCF67 (AR) の異常に因る。

6. 補体欠損症の中では，オプソニンとして 重要な C3, C5 の欠損症で呼吸器感染反復が認 められる。

そのほか, Wiskott-Aldrich 症候群や IgG 2 サブクラス異常症も呼吸器感染反復が知られて いる。

以上，免疫ネットワークに先天的障害を有す る免疫不全症に見られる反復呼吸器感染につい て紹介した。呼吸器感染における免疫系の役割 の重要性の理解と, 他疾患における呼吸器感染 反復の機序を考える上で参考になれば幸いであ る。

今回の発表は名古屋大学小児科免疫研究室鳥 居新平, 松岡道子, 岡田純一, 水野周久, 柘植 郁哉, 蒲池吉朗, 阿部徳一郎らとの共同研究に よる。 